\title{
Правовая оценка применения насилия негосударственными структурами
}

\author{
(C) Овчаров Артем Валерьевич, \\ кандидат юридических наук, научный сотрудник \\ сектора уголовного права, криминологии и \\ проблем правосудия ИГП РАН
}

\begin{abstract}
Аннотация. Статья посвящена рассмотрению вопроса возможности наделения негосударственных структур, а именно частных военных и охранных компаний, правом на применение насилия. В статье кратко рассматривается история вопроса права государства на легитимное насилие как составляющей государственного суверенитета в работах различных исследователей. Автором анализируется деятельность частных военных компаний в современных военных конфликтах, приводятся различные факты их деятельности и делается вывод о том, что наделение подобных структур правом на насилие с одной стороны разрушает государство, а с другой порождает преступность в военной сфере.

Ключевые слова: суверенитет, легитимное насилие, происхождение государства, кризис современной цивилизации, глобализация, преступность, военный конфликт, частная военная компания, государство.
\end{abstract}

\section{Legal assessment of the use of violence by non-state structures}

(C) Ovcharov A.V.,

Candidate of Legal Sciences, Researcher of the Sector of Criminal Law, Criminology and Problems of Justice of the IGP RAS

\begin{abstract}
The article is devoted to the consideration of the possibility of granting non-state structures, namely private military and security companies, the right to use violence. The article briefly examines the history of the issue of the state's right to legitimate violence as a component of state sovereignty in the works of various researchers. The author analyzes the activities of private military companies in modern military conflicts, provides various facts of their activities and concludes that granting such structures the right to violence on the one hand destroys the state, and on the other generates crime in the military sphere.

Keywords: sovereignty, legitimate violence, origin of the state, crisis of modern civilization, globalization, crime, military conflict, private military company, state.
\end{abstract}

Происходящая в современном мире трансформация общества, государства и права $^{1}$ актуализирует целую совокупность проблем, стоящих перед мировым сообществом. Угрозы и вызовы, с которыми человечество имеет дело в последние десятилетия, приобрели настолько сильный и системный характер, что создают реальную опасность для современной цивилизации. Именно цивилизация становится главным объектом воздействия, так как проблемы, о которых идет речь, занимают все глобаль-

${ }^{1}$ Савенков А.Н. Государство и право в период кризиса современной цивилизации: монография. М.: Проспект, 2020. ное пространство, затрагивая самые глубинные и чувствительные основы устройства современной мировой политической и правовой системы, экономику, культуру и другие сферы жизни мирового сообщества. Очевидным становится тот факт, что нынешние структуры и формы обеспечения стабильности функционирования и развития государства и общества оказываются не способными для противостояния многочисленным посягательствам, создающим угрозу ${ }^{2}$. Исследования философов, психологов, социологов, правоведов констатируют существенное влияние изменений

\footnotetext{
${ }^{2}$ Там же. С. 7.
} 
социально-экономических условий бытия на состояние социальной психологии и деформацию индивидуального и группового правосознания людей ${ }^{1}$.

Одной из возникших в условиях глобализации проблем является ослабление государств, что, по нашему мнению, изменяет саму сущность понятия государства. Традиционно, в научной и учебной литературе любое государство определялось через совокупность признаков (территориальная целостность, наличие публичной власти, право на законотворчество и т.д.). Одним из таких признаков всегда считалось обладание государством силовым аппаратом, имеющим право на легальное применение насилия.

Проблема права государства на легитимное насилие является одной из старейших научных проблем как общей теории государства и права, так специализированных отраслей права. Для правильного понимания того, почему любое государство обладает рассматриваемым правом и возможно ли его делегирование негосударственным структурам, обратимся к истории данного вопроса. Традиционно право на насилие государства, как самой сильной власти на определенной территории, рассматривается через призму государственного суверенитета. В литературе не раз отмечалось, что такой признак государства, как суверенитет неразрывно связан с правом государства на легитимное насилие, находящееся в отражении в национальной политике государства, являясь инструментом в руках государства для охраны безопасности от разных видов преступности для сохранения целостности государства и его самоопределения ${ }^{2}$.

Рассматривая вопрос права государства на насилие, следует сказать, что насилие явилось в свое время основополагаю-

\footnotetext{
${ }^{1}$ Трансформация парадигмы права в цивилизационном развитии человечества : Доклады членов Российской академии наук / под общ. ред. чл.-корр. РАН А.Н. Савенкова. М.: ИГП РАН, 2019.

${ }^{2}$ Серов Е.А. Характеристика государства и права с точки зрения права на легитимное насилие (М. Вебер, К. Маркс, Ф. Энгельс, В.И. Ленин, К. Шмитт, Л. Гумпилович, Е. Дюринг, К. Каутский, Г. Еллинек) // Аграрное и земельное право. 2016. № 10 (142). С. 37.
}

щим понятием для одной из теорий происхождения государства и права. Она так и называлась - теория насилия или социологическая теория и была весьма популярна со второй половины 19 в. Ее основателями считаются немецкий философ и экономист Евгений Дюринг и польский социолог и государствовед Людвиг Гумпилович. Данная теория основной причиной возникновения государства считает завоевание одних народов другими, т.е. насилие.

По мнению Л. Гумпиловича, взаимодействие народов, рас или социальных групп является сущностью любого социального явления. Это взаимодействие всегда основывается на подчинении одних другим ради собственных жизненно важных интересов и сопровождается насилием. Основную же причину возникновения государства автор видел в борьбе племён между собой за владение собственностью и порабощения побеждённых, превращая их в классы и сословия, предшествуя государству ${ }^{3}$.

Другой представитель рассматриваемой теории - Е. Дюринг основывал насилие на таких факторах, как социальное неравенство, эксплуатация и нищета. По его мнению, собственность, право и государство являют собой результат насилия одной части общества над другой, а любая политическая сила значима для развития государства, когда она имеет централизованный характер действующего закона, исходящего из национального права, распространяющего влияние на всю территорию государства ${ }^{4}$.

Говоря о теории насилия нельзя не упомянуть и такого философа, как К. Каутский, который сводилразвитие общества к демократии разных её типов, сложившихся в разных исторических условиях, выраженных в самоопределение нации. Постепенно, по его мнению, общество отрицает демократию при объединении племен, и расширение территории встаёт над демократией, образуя государство, отри-

\footnotetext{
${ }^{3}$ Гумпилович Л. Общее учение о государстве. СПб, 1910. C. 331.

${ }^{4}$ Дюринг Е. Ценность жизни СПб., 1894. М., 2000. С. 64.
} 
цающее демократию и управляющееся посредствам насилия ${ }^{1}$.

Традиционно, основоположником концепции монополии государства на насилие считается М. Вебер, который видел в насилии инструмент защиты государственного суверенитета различными общественными институтами. Теория М. Вебера не устанавливала грань легитимного насилия, где кончается закон и начинается злоупотребление властью по защите государственного суверенитета ${ }^{2}$.

Исследователь не разделял институты власти на государственные и общественные, выделяя только общественные, обладающие своей достаточной легитимностью в обществе. Общественные институты, по его мнению, не имеют правоустанавливающего характера. Они решают проблемы общества с точки зрения морали, морально-нравственных норм и обычаев, характерных данному обществу в тот или иной период его развития. М. Вебер не выделяет государственные институты власти, которые не могут иметь моральнонравственный характер.

По Веберу, существует три группы оснований для легитимного насилия. Это:

- господство патриархального князя, при котором во главу угла ставятся обычаи и традиции того или иного общества (примером могут служить различные восточные деспотии);

- харизматичное господство, основанное на личных качествах человека;

- легальное господство, основывающееся на обязательном подчинении закону и правовому порядку (в качестве примера автором называется парламентско-конституционное государство).

Государственный суверенитет по М. Веберу опирается не только на легитимное насилие, но и на политическое господство суверена, которое зиждется на социальном почёте и материальном вознаграждении. Развитие современного государства начинается с лишения дру-

\footnotetext{
${ }^{1}$ Каутский К. От демократии к государственному рабству. Берлин, 1922. С. 18-44.

2 Вебер М. Политика как призвание и профессия

/ Избранные произведения. М., 1990. С. 658.
}

гих суверенов права собственности и права на легитимное насилие в отношении их собственности, а также с подчинения их единому закону и верховной власти одного суверена. Одной из форм правления в концепции М. Вебера является плутократия, в рамках которой политики живут для политики, а не засчёт неё, используя своё господство в своих экономических интересах.

Управленческая система М. Вебера не имеет в своей основе систему разделения властей с чётким набором прав и обязанностей, а выглядит как сословная пирамида, во главе которой стоит суверен, обладающий абсолютной властью и системой карательных органов, которые наделены исключительным правом на легитимное насилие.

Монополию на насилие автор считал специфической функцией, которую не могут нести другие организации и общественные институты. Отсюда монополия на насилие выступает для него критерием выделения государства как особой организации и специфического института.

Особый подход к вопросам государственного суверенитета и права государства на насилие имеет материалистическая теория происхождения государства К. Маркса, Ф. Энгельса и В.И. Ленина. Ее основой является право на легитимное насилие в борьбе с асоциальными элементами ${ }^{3}$. Сам термин «асоциальный элемент» в марксистской теории суверенитета имеет весьма широкую трактовку.

Концепция рассматривает зарождение государства с точки зрения частной собственности, и появление классов, которые утверждают свою волю в праве, рождая органы легитимного насилия, как аппарата управления и принуждения. Становление государства рассматривается с точки зрения производственных отношений и собственности, находящейся в руках суверена, а само государство и право есть продукт насилия, возникшего в результате самоопределения народов. С образованием публичной власти, со своими вооружёнными

\footnotetext{
3 Ленин В.И. Полное собрание сочинений. 5-е изд. М.: Изд. политической лит., 1967. С. 663.
} 
силами, с системой налогов и с территориальным делением община становится государством ${ }^{1}$.

Само государство как организация общества вместе со всей своей системой карательных органов является пережитком прошлого, которое постепенно отмирает, образуя новое бесклассовое общество $^{2}$.

Органы легитимного насилия не разделены на правоохранительные, а имеют вид охраны суверена и поданных, постепенно развиваясь становятся органами для защиты прав и интересов общества. Государство, согласно Ф. Энгельсу, есть продукт общества для разрешения противоречий между классами.

Исходя из вышеизложенного можно сделать вывод, что в той или иной степени, практически любая теория происхождения государства тем или иным образом связывала понятие государства с его правом на легитимное насилие. Признаком любого государства является его монополия на легитимное насилие, используемое государством для обеспечения внутренней и внешней безопасности. Для выполнения этой функции любое государство создает аппарат принуждения. Это армия, полиция, органы разведки и контрразведки, службы безопасности и иные силовые структуры, имеющие различные названия и разные полномочия.

В литературе отмечалось, что насилие в современном мире осуществляется организованным образом, имея все черты институционализированного политического процесса, в глобальных масштабах и новых формах. Используется физическое, символическое, информационное, культурное и прочие виды насилия с целью подчинения воли масс людей в экономических и политических интересах определенных социальных групп. Даже самые благие цели, как, например, освобождение от эксплуататорского или колониального гнета, достигаются с помощью насильственных методов. Политическое насилие

\footnotetext{
${ }^{1}$ Маркс К., Энгельс Ф. Избранные произведения. В 3-х т. Т. 3. М.: Политиздат, 1986. С. 369.

2 Маркс К. Энгельс Ф. Сочинение. 2-е изд. М., 1955-1961. T. 48. C. 157; T. 46 / 1 . C. 491.
}

является одним из принципов концепции государства-монополиста на применение легитимного насилия. Применение насилия государством носит легитимный характер по причине существования общественного договора о вручении народом государственной власти монопольного права на применение силы с целью защиты общества от преступности, нарушений общественных (правовых) норм, защиты территории государства от внешнего врага и выполнения других функций. Никто, кроме государства, не имеет права применять силу по отношению к индивидам, группам индивидов, обществу в целом ${ }^{3}$.

Тем не менее, практика последних десятилетий говорит о том, что все чаще государства наделяют правом на применение насилия организации, не входящие в систему государственной власти. Одними из таких организаций являются частные военные и охранные компании (ЧВОК).

Чем же занимаются данные организации? Всех их целесообразно разделить на четыре группы:

1) военные компании или компании военных услуг (military provider companies). В сферу деятельности таких компаний входит предоставление клиентам услуг, непосредственно связанных с ведением боевых действий. Сотрудники данных компаний непосредственно участвуют в различных боевых операциях и столкновениях;

2) компании по предоставлению консалтинговых услуг (military consulting companies). Такие компании специализируются на тренировочной деятельности всевозможных армейских подразделений, на обучении работе с новыми типами вооружений, а также на консультировании государственных силовых структур по вопросам, связанным с реформированием вооруженных сил. Кроме того, к сфере деятельности подобных компаний относится и стратегическое планирование;

\footnotetext{
3 Хагуш С. Приватизация насилия как фактор разрушения монополии государства на легитимное насилие // Наука и образование: хозяйство и экономика; предпринимательство; право и управление. 2019. № 2 (105). С. 138.
} 
3) компании по предоставлению логистических услуг (military support companies). ЧВОК данной группы в первую очередь осуществляют деятельность по строительству военных объектов, но вместе с тем занимаются и тыловым обеспечением войск. К данной группе следует так же относить те компании, чьей специализацией является обслуживание технически сложных армейских систем вооружения и военных компьютерных систем;

4) компании по предоставлению частных охранных услуг. Данные компании также называют компаниями по безопасности (private security companies). Деятельность этих компаний сосредоточена на оценке рисков от военных операций, кризисном менеджменте и консалтинге безопасности. Кроме того, ЧВОК данной группы занимаются непосредственной охраной объектов, предоставляют услуги телохранителей. Подобные компании занимаются разминированием территорий и объектов и обучением различных как армейских подразделений, так и подразделений полиции ${ }^{1}$.

Рассматриваемые организации в последние десятилетия стали не только полноценными участниками рынка военной силы, а значит организациями, имеющими право на легальное применение насилия, но еще и развиваются огромными темпами. Совсем недавно, по оценке ряда исследователей, ежегодный оборот этого рынка составлял 100-120 млрд. долл., по оценке других - 180 млрд. 75 \% этого оборота приходилось более чем на 700 западных компаний ${ }^{2}$. По оценкам ряда специалистов на 2021 г., на международном рынке ЧВОК осуществляют свою деятельность более чем в 110 странах мира, а их совокупный объем рынка превышает 350 млрд. долл. На мировом рынке ЧВОК сегодня

\footnotetext{
${ }^{1}$ Овчаров А. Частные военные компании: уголовно-правовой аспект // Военное право. 2018. № 6 (52). С. 247.

${ }^{2}$ Холиков И.В., Сайфуллин Э.К., Окоча В.А. Современные тенденции правового регулирования деятельности частных военных и охранных компаний // Право в Вооруженных Силах военно-правовое обозрение № 12 (264), 2019. С. 67.
}

трудится более 1 млн. человек ${ }^{3}$. Все большее развитие ЧВОК и анализ их функционирования на рынке порождает вопросы не только о законодательной регламентации их деятельности, но и вопросы самой возможности существования рассматриваемых организаций.

Наблюдаемому стремительному развитию ЧВОК есть целый ряд объяснений.

Прежде, всего это крайне высокий профессионализм военного персонала ЧВОК. (Что вполне естественно. Конечно же наниматель предпочтет оплачивать работу профессионала, нежели дилетанта). Достаточно часто профессионализм сотрудников ЧВОК отличается от профессионализма регулярной армии, солдаты которой несут срочную службу и достаточно часто имеют только начальную военную подготовку. Следствием такого «профессионализма» является и абсолютная беспристрастность бойцов ЧВОК. Они не обременены отстаиванием национальных интересов того или иного государства, религиозными или нравственными догмами и т.Д.

Во-вторых, когда то или иное государство нанимает ЧВОК, оно автоматически избегает проблем, связанных с социальным недовольством гражданского населения. Нет мобилизации населения, отсутствует общественный резонанс по поводу гибели своих сограждан. Организации, созданные по образу и подобию «комитетов солдатских матерей» молчат, а численность погибших не будет учитываться в официальной статистике.

Кроме того, частные военные и охранные компании, как правило, действуют на территориях военных конфликтов инкогнито. Они отстаивают политические, экономические или иные интересы нанимателя без официального вмешательства в военные действия. Такое положение вещей исключает международный конфликт, введение каких-либо санкций против одной из сторон.

\footnotetext{
${ }^{3}$ https://www.ng.ru/blogs/filatov/zamakh-na-rubl-udarna-kopeyku-zakonodatelnaya-sudba-rossiyskikhchvk.php. (Дата обращения 12.09.2021).
} 
Однако, следует отметить, что подобное «удобство» в найме ЧВОК различными государствами имеет и обратную сторону.

Анализ практики деятельности ЧВОК в мире позволяет сделать вывод об огромном числе случаев совершения ими преступлений.

Так, во время боевых действий в Ираке и Афганистане ЧВОК Black water стремилась к правовому иммунитету для своих сотрудников, что приводило к формированию ощущения безнаказанности у вооруженных людей, которые этим пользовались на практике. В результате, у бойцов данной ЧВОК порог принятия решения на применение оружия в отношении гражданских лиц оказался занижен, что приводило к постоянным инцидентам. При охране делегации США в Багдаде сотрудники Black water на площади Нисур расстреляли 17 человек, включая женщин и детей. Более 20 человек получили ранения различной степени тяжести ${ }^{1}$.

В конфликте, имеющем место на территории Украины, активное участие принимали «территориальные батальоны» и «батальоны Нацгвардии», которые финансировались частными лицами. Такие батальоны использовались и в ходе так называемой «антитеррористической операции» на востоке Украины в 2014 г. При этом, по данным ряда авторов, изучавших названные военные организации, «имелись многочисленные свидетельства о совершении ими ряда военных преступлений» ${ }^{2}$.

В 2018 г. огромный политический резонанс получило убийство в Центральной Африканской Республике трех российских журналистов, которое некоторые средства массовой информации связывали с их расследованием деятельности в этой стране

\footnotetext{
1 https://riafan.ru/1423764-blackwater-kak-chuvstvovsedozvolennosti-pogubilo-krupneishuyu-

amerikanskuyu-chvk. (Дата обращения 08.08.2021).

2 Смирнов С. Частные военные компании как угроза государственному суверенитету современного государства // Правовое государство: проблемы понимания и реализации : Сборник статей Международной научно-практической конференции, посвященной 10-летию журнала «Правовое государство: теория и практика». М., 2015.
}

ЧВК Вагнера, якобы принадлежавшей российскому олигарху Е. Пригожину, которого «... подозревают в организации предвыборных кампаний при помощи наемников и политических экспертов в обмен на право на добычу полезных ископаемых. Пригожин, в свою очередь,это отрицает» ${ }^{3}$.

Подобных фактов в средствах массовой информации приводилось огромное количество, особенно касаемо деятельности ЧВОК, подконтрольных правительству США. В литературе указывался целый перечень негативных тенденций в работе частных военных и охранных компаний. Это:

1) полное искажение официальной статистики;

2) «специалисты» ЧВК не несут никакой уголовной ответственности за содеянные ими преступления в связи с беззаконием во время конфликта в государстве;

3) «специалисты» ЧВК не прописаны в международном гуманитарном праве (МГП), а значит не могут иметь статуса военнопленного;

4) опыт ведения совместных боевых действий «специалистов» ЧВК и регулярной армии США в Ираке показал, что жесткие методы ведения боевых действий наёмников влекут за собой негативное влияние на авторитет регулярной армии, так как местное население не видит разницы между бойцами. В свою очередь это приводит к накалу обстановки, и понижению доверия граждан к армии в зоне конфликта;

5) создание коррупционных схем и отмыв денег через ЧВК правительством;

6) силовое вмешательство Транснациональных Компаний во внутренние дела государств для достижения политической и экономической выгоды ${ }^{4}$.

Основной причиной происходящего, по нашему мнению, является следующее. Частные военные и охранные компании фактически имеют право абсолютно без-

\footnotetext{
${ }^{3}$ Хагуш С. Указ. соч. С. 140.

4 Банадыков Я. Значение ЧВК в новых войнах // Донецкие чтения 2020: образование, наука, инновации, культура и вызовы современности / Материалы V Международной научной конференции. Под общ. ред. С.В. Беспаловой. Донецк, 2020. С. 127.
} 
наказанной деятельности несмотря на то, что как в международных, так и в немеждународных конфликтах выявляется наличие нормы обычного МГП о судебном преследовании лиц, виновных в совершении военных преступлений ${ }^{1}$. В частности, государства несут основную ответственность за расследование сообщений о нарушениях и судебное преследование лиц, обвиняемых в совершении серьезных нарушений МГП ${ }^{2}$.

Дополнительный протокол № 1 к Женевским конвенциям от 12 августа 1949 г., касающийся защиты жертв международных вооруженных конфликтов (подписан в г. Женеве 8 июня 1977 г.) в ст. 43 определяет состав вооруженных сил сторон, находящихся в конфликте. Так, вооруженные силы стороны, находящейся в конфликте, состоят из всех организованных вооруженных сил, групп и подразделений, находящихся под командованием лица, ответственного перед этой стороной за поведение своих подчиненных, даже если эта сторона представлена правительством или властью, не признанными противной стороной.

Такие вооруженные силы подчиняются внутренней дисциплинарной системе, которая, среди прочего, обеспечивает соблюдение норм международного права, применяемых в период вооруженных конфликтов и недопущение ими преступлений. К сожалению, такое положение вещей не распространяется на деятельность ЧВОК.

В литературе отмечалось, что ЧВОК успешно маскируют фактическое наёмничество под охранную, военнологистическую и иную подобного рода деятельность, не запрещённую нормами международного права. При этом стремятся исключить любые утечки информации, которые могли бы пролить свет на их реальную роль в том или ином конфликте и содействовать установлению системы

\footnotetext{
1 Дамаскин О.В., Холиков И.В. Военные аспекты международного гуманитарного права // Военное право. 2017. № 2. С. 216.

2 Дамаскин О.В., Холиков И.В. Современные проблемы международного гуманитарного права // Современное право. 2017. № 5. С. 108.
}

гражданского контроля за ними. В этом плане ЧВК остаются предельно закрытыми организациями, реальная деятельность которых раскрывается только вследствие скандалов или расследований ${ }^{3}$.

Также набирает оборот использование частных морских охранных компаний для обеспечения безопасности морского судоходства, где тоже далеко не все гладко с точки зрения правового регулирования применения ими вооруженной силы ${ }^{4}$.

Таким образом, суммируя все вышеизложенное, можно сказать, что передача государством права на легитимное насилие частным структурам, с одной стороны, ведет к потере государственного контроля над сферой безопасности и создает условия для её частичной или полной приватизации ЧВОК в будущем, а с другой - порождает рост преступности в военной сфеpe. В этой связи наиболее правильной представляется российская позиция, выраженная еще в 2014 г. в Военной доктрине Российской Федерации, утвержденной Президентом Российской Федерации 25 декабря 2014 г. Данный документ в п. 12 раздела II «Военные опасности и военные угрозы Российской Федерации» называет деятельность иностранных частных военных компаний в районах, прилегающих к государственной границе Российской Федерации и границам ее союзников, одной из основных внешних военных опасностей. А в п. 15 определяет участие в военных действиях иррегулярных вооруженных формирований и частных военных компаний в качестве характерной черты и особенности современных военных конфликтов.

\footnotetext{
${ }^{3}$ Манойло А., Зайцев А. Международно-правовой статус частных военных компаний // Вестник Российской академии наук.. 2020. Т. 90. № 1.. С. 55; Корякин В.М., Харитонов В.С. Понятие «наемничество» в контексте деятельности частных военных компаний // Право в Вооруженных Силах - военноправовое обозрение. 2019. № 4 (261). С. 95-101.

${ }^{4}$ См. подробнее: Холиков И.В., Окоча В.А. Применение вооруженной силы частными морскими охранными компаниями: динамика границ и специфика правового регулирования в современном мире // Журнал российского права. 2020. № 12. C. $147-158$.
} 
В заключение хотелось бы процитировать Н. Макиавелли, который говорил, что право на применение вооруженного насилия не может быть дано частным лицам, а только государству, поскольку частные лица в войне действовать честно не могут (Макиавелли Н. Государь. Рассуждения о первой декаде Тита Ливия. Ростов н/Д: Изд-во «Феникс», 1998. С. 576).

\section{Библиография}

1. Банадыков, Я. Значение ЧВК в новых войнах / Я. Банадыков // Донецкие чтения 2020: образование, наука, инновации, культура и вызовы современности / Материалы V Международной научной конференции. Под общ. ред. С.В. Беспаловой. - Донецк, 2020.

2. Дамаскин, O.В. Военные аспекты международного гуманитарного права / О.В. Дамаскин, И.В. Холиков // Военное право. 2017. 一 № 2. - С. 214-221.

3. Дамаскин, О.В. Современные проблемы международного гуманитарного права / О.В. Дамаскин, И.В. Холиков // Современное право. - 2017. - № 5. - С. 104-111.

4. Корякин, В. М., Харитонов, В. С. Понятие «наемничество» в контексте деятельности частных военных компаний / В. М. Корякин, В. С. Харитонов // Право в Вооруженных Силах - Военноправовое обозрение. - 2019. — № 4 (261). C.95-101.

5. Манойло, А. Международно-правовой статус частных военных компаний / А. Манойло, А. Зайцев // Вестник Российской академии наук. 2020. - T. 90. - № 1 .

6. Овчаров, А.В. Частные военные компании: уголовно-правовой аспект / А.В. Овчаров // Военное право. - 2018. - № 6 (52).
7. Савенков, А.Н. Государство и право в период кризиса современной цивилизации : монография / А.Н. Савенков. - М.: Проспект, 2020.

8. Серов, Е.А. Характеристика государства и права с точки зрения права на легитимное насилие (М. Вебер, К. Маркс, Ф. Энгельс, В.И. Ленин, К. Шмитт, Л. Гумпилович, Е. Дюринг, К. Каутский, Г. Еллинек) / Е.А. Серов // Аграрное и земельное право. - 2016. - № 10 (142).

9. Смирнов, С. Частные военные компании как угроза государственному суверенитету современного государства / С. Смирнов // Правовое государство: проблемы понимания и реализации : Сборник статей Международной научнопрактической конференции, посвященной 10-летию журнала «Правовое государство: теория и практика». - М., 2015.

10. Трансформация парадигмы права в цивилизационном развитии человечества : Доклады членов Российской академии наук / Под общ. ред. чл.-корр. РАН А.Н. Савенкова. - М.: ИГП РАН, 2019.

11. Хагуш, С. Приватизация насилия как фактор разрушения монополии государства на легитимное насилие / С. Хагуш // Наука и образование: хозяйство и экономика; предпринимательство; право и управление. - 2019. - № 2(105.

12. Холиков, И.В. Применение вооруженной силы частными морскими охранными компаниями: динамика границ и специфика правового регулирования в современном мире / И.В. Холиков, В.А. Окоча // Журнал российского права. - 2020. — № 12. - C. 147-158.

13. Холиков, И.В. Современные тенденции правового регулирования деятельности частных военных и охранных компаний / И.В. Холиков, Э.К. Сайфуллин, В.А. Окоча // Право в Вооруженных Силах - военно-правовое обозрение. — 2019. — № 12 (264). — С. 65-71. 